\title{
MARKING WITH PIGMENTS FOR IDENTIFICATION OF FLIES IN EXPERIMENTAL POPULATIONS OF Megaselia scalaris LOEW
}

\author{
MANZATO, A. J. ${ }^{1}$ and TADEI, W. J. ${ }^{2}$ \\ ${ }^{1}$ Departamento de Ciências de Computação e Estatística, IBILCE-UNESP, São José do Rio Preto, SP, Brazil \\ ${ }^{2}$ Departamento de Biologia, IBILCE-UNESP, São José do Rio Preto, SP, Brazil \\ Correpondence to: Wlademir João Tadei, IBILCE, UNESP, Rua Cristóvão Colombo, 2265, C.P. 136, \\ CEP 15054-000, São José do Rio Preto, SP, Brazil, e-mail: wjtadei@bio.ibilce.unesp.br \\ Received August 8, 2002 - Accepted January 24, 2003 - Distributed May 31, 2004
}

(With 1 figure)

\begin{abstract}
The insect marking technique of Tadei \& Mourão (1976) is until now the only experimental method allowing real-age determination of each individual in a population and, consequently, determination of age structure in a given population. We propose an improvement of this technique, used here to determine the population age structure of the geographical strain SR of the Megaselia scalaris Loew (Diptera; Phoridae), maintained by serial transfer technique at constant temperatures $25 \pm 1.0^{\circ} \mathrm{C}$ and $20 \pm 1.0^{\circ} \mathrm{C}$. Determining the age structure allowed the calculation of the real longevity of the flies and the identification of the effect of temperature decisive factors in these are the technique of marking insects, because otherwise we would only have an estimate, and depending on mistakes there in, the effect of the determinant factor (temperature) cannot be detected.
\end{abstract}

Key words: technique for marking insects, Megaselia, populations, age structure.

\section{RESUMO}

\section{Marcação com tinta para identificação das moscas em populações experimentais de Megaselia scalaris Loew}

A técnica de marcação de insetos de Tadei \& Mourão (1976) é, até o momento, o único método experimental que possibilita determinar a idade real de cada indivíduo na população e, conseqüentemente, determinar a estrutura etária da mesma. Para isto propomos um aprimoramento dessa técnica, utilizada aqui para determinar a estrutura etária de populações da linhagem geográfica SR do díptero forídeo Megaselia scalaris Loew, mantidas pela técnica da transferência seriada em câmaras com temperatura constante de $25 \pm 1,0^{\circ} \mathrm{C}$ e $20 \pm 1,0^{\circ} \mathrm{C}$. O estabelecimento da estrutura etária permitiu calcular a longevidade real das moscas e detectar o efeito ambiental temperatura, sendo fator determinante neste trabalho a marcação dos insetos, pois se não o fosse, teríamos somente estimativas e, dependendo do erro cometido na estimação, o efeito do fator de interesse (temperatura) poderia não ser detectado.

Palavras-chave: técnica de marcação de insetos, Megaselia, populações, estrutura etária.

\section{INTRODUCTION}

The age determination of each individual in populations is important in understanding population dynamics. Specifically, the formulation of a model allowing the establishment of population age structure could make possible the study of birth and death processes so that some characteristics like birth rate, mortality, and longevity, which constitute important parameters for understanding the whole process, could be described. Tadei \& Mourão (1976) proposed a technique developed for Drosophila which made possible the marking of insects. Age of individuals in the population could be identified after etherized flies were spread out on a sheet of white paper and sprayed using a plastic flask (like those commonly 
used for deodorants) which released a fine mist of paint particles. The paint solution had the following composition: $100 \mathrm{ml}$ of distilled water, $50 \mathrm{ml}$ of Coralmur white base, and from 8 to $10 \mathrm{~g}$ of Coralcor pigment paste. According the pigment paste was of different colors according to its purpose. For the marking process, the mist had to be of fine droplets, so that the marking process wold have no effect on mortality and, consequently, on individual longevity. In Corradi \& Mourão (1980), and Corradi, et al. (1980), this technique was used with Drosophila.

The current objective was to introduce modification of the technique for marking insects, designed to apply to experimental populations of Megaselia scalaris (Diptera; Phoridae), as well as to determine the environmental temperature effect, in an experiment planned to ascertain population age structure and the real longevity of the flies.

\section{MATERIAL AND METHODS}

The adaptation of the Tadei and Mourão technique uses a painting device adapted to a low pressure air compressor (Jetmaster II - 2.3 PCM). The device constructed according to the principle of the Venture tube. It consisted of two pieces of copper capillary tube perpendicularly placed, so that two of the tips were in close proximity (Fig. 1). The air compressor was connected to the extremity of one of the tubes through a rubber hose. The extremity of the other was submerged in a recipient containing paint. When air is released by the compressor, suction occurs and, through the two extremities very in close proximity, the paint mist forms marks the etherized flies.

Although use of this equipament facilitated marking, it demanded too much work; besides, as the paint dried, the flask would clog, a problem solved by using thin copper threads for cleaning. This modification required a change in the marking paint composition. The results combining two products Coral, both soluble in water: Coralmur, a white latex base, and Coralcor pigments whose mixture follows a factory code. The proportion, tested in a pilot experiment and accepted as having no effect on the fly mortality, specifically on Megaselia scalaris Loew (Diptera, Phoridae), called for two portions of distilled water for one of paint.

With SR strain flies from Seropédica, the State of Rio de Janeiro, Brazil, kept in the Biology
Department of IBILCE-UNESP of São José do Rio Preto, six experimental populations were started and maintained at constant temperature $\left(25 \pm 1.0^{\circ} \mathrm{C}\right.$ and $20 \pm 1.0^{\circ} \mathrm{C}$ ), with three replicas at each temperature. The serial transfer technique (Buzzati-Traverso, 1955, cf. Tadei \& Mourão, 1981) was used to conserve the populations. This technique consists of introducing the founder flies into a $250 \mathrm{ml}$ bottle with fresh medium (day 1-Monday) to deposit their eggs for two days. They were then transferred (day 3-Wednesday), without etherization, to another bottle with fresh medium for two more days, and after this period they were again transferred (day 5-Friday), without etherization, to another new bottle where they stayed for three days. When they started to emerge from the pupae, the imagoes were collected three times a week, on the same days that the population was transferred to the new bottles (Monday, Wednesday, and Friday). These young flies were etherized, counted, and marked with differentcolor paints for identification and age structure study, and then added to the adult population. The adult flies were thus maintained in a single bottle with fresh medium, while the other bottles contained eggs, larvae, pupae, and recently-emerged flies. Every 7 days (Mondays), before the young fly addition, the adults were etherized, counted for sex and color, and soon afterwards transferred to a new bottle. The populations kept at constant temperature $\left(25 \pm 1.0^{\circ} \mathrm{C}\right)$ were maintained in 15 bottles, while the populations at $20 \pm 1.0^{\circ} \mathrm{C}$ were kept in 18 bottles.

\section{RESULTS AND DISCUSSION}

The monday censuses lasted 36 weeks for, the bottles with the adults of the population; marking allowed us to identify flies with 3, 5, 7, 10, 12, 14, $17,19,21, \ldots$ days of age. Thus, the population the age structure was able to be described and is contained in Tables 1 and 2, which present only female data.

The data produced at $25^{\circ} \mathrm{C}$ (Table 1) show that $98 \%$ of the flies were concentrated in the 314 day age groups while at $20^{\circ} \mathrm{C}$ (Table 2 ) the same percentage occurred in the 3-21 day age groups.

Tables 1 and 2 show that at $25^{\circ} \mathrm{C}$ the concentration of flies of 3,5, and 7 days was greater than that at $20^{\circ} \mathrm{C}$, when the relative frequencies of these classes were reduced and the frequencies of the next classes consequently increased. At $20^{\circ} \mathrm{C}$ there were survivors until the twenty-eighth day, whereas at 
$25^{\circ} \mathrm{C}$, after the twenty-first day, there were practically no more survivors.

The $95 \%$ confidence intervals of the replicas 1 , 2 , and 3 are described in Table 3 , respectively, for temperatures of $25^{\circ} \mathrm{C}$ and $20^{\circ} \mathrm{C}$. For each age, at each temperature, the overlapping (intersection) of confidence intervals of replicas 1,2 , and 3 is observed, showing that the replica effect is not significant.
Table 4 shows $95 \%$ confidence intervals for the means of replicas 1,2, and 3, at temperatures of $25^{\circ} \mathrm{C}$ and $20^{\circ} \mathrm{C}$. At each age, for the two temperatures, the intervals are disjointed (empty intersection), except those of 12, 14, and 17 days. This result shows the significant effect of temperature on the population size and the distribution of this effect on the age of the flies.

Fig. 1 - Illustration of the painting device: 1 . rubber hose; 2. copper capillary tube $2 \mathrm{~mm}$ in diameter; 3 . copper capillary tube $1 \mathrm{~mm}$ in diameter; 4. paint recipient; and 5. support for copper tubes.

TABLE 1

Mean number of females ( $\quad$ ) by age groups (in days), for the populations $\mathrm{SR}_{1}, \mathrm{SR}_{2}$, and $\mathrm{SR}_{3}$ kept at $25^{\circ} \mathrm{C}$.

\begin{tabular}{|c|c|c|c|c|}
\hline \multirow{3}{*}{ Days } & \multicolumn{4}{|c|}{ Replicates } \\
\hline & $\mathbf{S R}_{1}$ & $\mathbf{S R}_{2}$ & $\mathbf{S R}_{3}$ & Mean \\
\hline & $\bar{X} \pm S_{\bar{X}}$ & $\bar{X} \pm S_{\bar{X}}$ & $\bar{X} \pm S_{\bar{X}}$ & $\bar{X} \pm S_{\bar{X}}$ \\
\hline 3 & $124.1 \pm 9.9$ & $121.3 \pm 9.9$ & $120.1 \pm 9.9$ & $121.8 \pm 5.7$ \\
\hline 5 & $88.3 \pm 9.9$ & $94.3 \pm 6.5$ & $85.7 \pm 6.4$ & $89.4 \pm 4.0$ \\
\hline 7 & $114.9 \pm 9.9$ & $108.1 \pm 9.9$ & $116.9 \pm 9.9$ & $113.3 \pm 6.0$ \\
\hline 10 & $41.5 \pm 5.9$ & $38.3 \pm 5.8$ & $37.1 \pm 6.0$ & $38.9 \pm 3.4$ \\
\hline 12 & $24.1 \pm 4.1$ & $23.2 \pm 3.4$ & $18.9 \pm 2.6$ & $22.0 \pm 2.0$ \\
\hline 14 & $20.9 \pm 3.8$ & $18.5 \pm 4.6$ & $19.5 \pm 4.5$ & $19.6 \pm 2.5$ \\
\hline 17 & $9.2 \pm 2.1$ & $3.6 \pm 1.0$ & $6.0 \pm 1.9$ & $6.2 \pm 1.0$ \\
\hline 19 & $3.7 \pm 1.4$ & $1.7 \pm 0.7$ & $0.9 \pm 0.4$ & $2.1 \pm 0.5$ \\
\hline 21 & $1.2 \pm 0.4$ & $0.7 \pm 0.4$ & $0.9 \pm 0.4$ & $0.9 \pm 0.2$ \\
\hline 24 & $0.4 \pm 0.1$ & $0.3 \pm 0.2$ & $0.2 \pm 0.1$ & $0.3 \pm 0.1$ \\
\hline 26 & $0.3 \pm 0.2$ & ----- \pm ---- & ---- \pm ---- & ----- \pm ---- \\
\hline 28 & $0.1 \pm 0.1$ & ----- \pm ---- & ----- \pm ---- & ----- \pm ---- \\
\hline
\end{tabular}




\section{TABLE 2}

Mean number of females $\left(\bar{X} \pm S_{\bar{X}}\right.$ ) by age groups (in days), for the populations $\mathrm{SR}_{1}, \mathrm{SR}_{2}$, and $\mathrm{SR}_{3}$ kept at $20^{\circ} \mathrm{C}$.

TABLE 3

The $95 \%$ confidence intervals of the populations $\mathrm{SR}_{1}, \mathrm{SR}_{2}$, and $\mathrm{SR}_{3}$, at $25^{\circ} \mathrm{C}$ at $20^{\circ} \mathrm{C}$. 
For longevity calculation, the Tadei \& Mourão (1981) formulation was used, as it takes into account the age structure of each population, obtaining this weighted average: $\quad, x_{\mathrm{i}}$ representing the fly age, and the relative frequency of observed flies in each age group.

The occurrence pattern of the age groups at $25^{\circ} \mathrm{C}$ and $20^{\circ} \mathrm{C}$, verified respectively in the three replicas, shows which age groups can determine the population size as a result of the temperature variation.

Table 5 presents the mean longevity values of the females at $25^{\circ} \mathrm{C}$ and $20^{\circ} \mathrm{C}$. The statistical test for replica effect, as expected, was not significant; but the t-Student unilateral test for verification of the temperature effect was significant $(\mathrm{t}=1.76$ and $\mathrm{p}=0.04<0.05)$, showing that the mean longevity of the flies at $20^{\circ} \mathrm{C}$ was superior to that at $25^{\circ} \mathrm{C}$.

The determination of the real mean longevity of the flies can only be done when the population age structure is experimentally established through the insect marking technique.

When the age structure of a population is unknown, the mean longevity of the flies can be estimated by Levene's method (cf. Dobzhansky and Pavlovsky, 1961).

TABLE 4

The $95 \%$ confidence intervals for the mean of the populations $\mathrm{SR}_{1}, \mathrm{SR}_{2}$, and $\mathrm{SR}_{3}$, at $25^{\circ} \mathrm{C}$ and $20^{\circ} \mathrm{C}$.

\begin{tabular}{|c|c|c|}
\hline \multirow{2}{*}{ Days } & \multicolumn{2}{|c|}{ Temperature } \\
\cline { 2 - 3 } & $\mathbf{2 5}^{\circ} \mathbf{C}$ & $\mathbf{2 0}{ }^{\circ} \mathbf{C}$ \\
\hline 3 & {$[110.6 ; 133.0]$} & {$[62.3 ; 70.3]$} \\
\hline 5 & {$[81.6 ; 97.2]$} & {$[43.6 ; 58.0]$} \\
\hline 7 & {$[101.5 ; 125.1]$} & {$[57.0 ; 77.0]$} \\
\hline 10 & {$[32.2 ; 45.6]$} & {$[22.3 ; 32.1]$} \\
\hline 12 & {$[18.1 ; 25.9]$} & {$[15.5 ; 22.9]$} \\
\hline 14 & {$[14.7 ; 24.5]$} & {$[22.1 ; 34.7]$} \\
\hline 17 & {$[4.2 ; 8.2]$} & {$[7.1 ; 11.7]$} \\
\hline 19 & {$[1.1 ; 3.1]$} & {$[4.2 ; 8.8]$} \\
\hline 21 & {$[0.5 ; 1.3]$} & {$[4.9 ; 10.7]$} \\
\hline 24 & {$[0.1 ; 0.5]$} & {$[1.7 ; 4.5]$} \\
\hline 26 & - & {$[0.5 ; 3.3]$} \\
\hline 28 & - & {$[0.1 ; 1.7]$} \\
\hline
\end{tabular}

\section{TABLE 5}

Mean longevity of females ( ) for experimental populations $\mathrm{SR}_{1}, \mathrm{SR}_{2}$, and $\mathrm{SR}_{3}$ kept at constant temperatures $\left(25 \pm 1.0^{\circ} \mathrm{C}\right.$ and $\left.20 \pm 1.0^{\circ} \mathrm{C}\right)$.

\begin{tabular}{|c|c|c|c|}
\hline \multirow{2}{*}{ Replicates } & $25 \stackrel{C}{C}$ & \multirow{2}{*}{ Replicates } & $20 \% \mathrm{C}$ \\
\hline & $\bar{X} \pm S_{\bar{X}}$ & & $\overline{\boldsymbol{X}} \pm S_{\bar{X}}$ \\
\hline $\mathrm{SR}_{1}$ & $7.2 \pm 0.6$ & $\mathrm{SR}_{4}$ & $9.1 \pm 0.8$ \\
\hline $\mathrm{SR}_{2}$ & $6.8 \pm 0.5$ & $\mathrm{SR}_{5}$ & $9.1 \pm 0.8$ \\
\hline $\mathrm{SR}_{3}$ & $6.8 \pm 0.5$ & $\mathrm{SR}_{6}$ & $9.0 \pm 0.8$ \\
\hline Mean & $6.9 \pm 1.0$ & Mean & $9.1 \pm 0.5$ \\
\hline
\end{tabular}


This is a mathematical model and, like all models, is a simplification of natural processes; as such, it is based on theoretical premises which describe the phenomenon, whether natural or experimental. This methodis, however, valid only as a model, when all the premises are satisfied. Thus, estimate reliability depends on that.

\section{REFERENCES}

BUZZATI-TRAVERSO, A. A., 1955, Evolutionary changes in components of fitness and other polygenic traits in Drosophila melanogaster populations. Heredity, 9: 153186.
CORRADI, M. A. S. \& MOURÃO, C. A., 1980, Stable age distribution in experimental populations of Drosophila. Brazil. J. Genetics., 3: 153-164.

CORRADI, M. A. S., MOURÃO, C. A. \& TADEI, W. P., 1980, Longevity in experimental populations of Drosophila. Brazil. J. Genetics., 3: 265-273.

DOBZHANSKY, Th. \& PAVLOVSKY, O., 1961, A futher study of fitness of chromosomally polymorphic and monomorphic population of Drosophila pseudoobscura. Heredity, 16: 169179.

TADEI, W. P. \& MOURÃO, C. A., 1976, A technique to mark insects. Ciência e Cultura, 28: 550.

TADEI, W. J. \& MOURÃO, C. A., 1981, Cyclic oscillations in population size of Drosophila sturtevanti. Brazil. J. Genetics., 4: 149-164. 